\title{
Fetuin-a expression profile in mouse and human adipose tissue
}

\author{
Abdelkrim Khadir ${ }^{1}$, Sina Kavalakatt ${ }^{2}$, Dhanya Madhu² and Ali Tiss $^{2^{*}}$
}

\begin{abstract}
Fetuin-A (Fet-A) was one of the first hepatokines to be reportedly linked to metabolic diseases. Fet-A was also suggested to be an adipokine, but its expression in the adipose tissue remains debatable. Here we compared the expression of Fet-A between human and mice adipose tissue biopsies as well as among human subcutaneous tissue and visceral adipose tissue primary cells, and mouse 3T3-L1 cells at various stages of differentiation. Fet-A was expressed in mice biopsies and cells but not in human biopsies and cells, except in visceral adipose tissue primary cells following differentiation. Although the marginal expression of Fet-A in human visceral adipose tissue, a major contribution of Fet-A expression in human adipose tissue to systemic Fet-A levels is discounted, but it could indicate specific local Fet-A action in the visceral adipose tissue.
\end{abstract}

Keywords: Fetuin-a, Adipose tissue, Human adipose primary cells, Mouse adipose tissue

\section{Main text}

The hepatokine fetuin-A (Fet-A) is linked to obesity and type 2 diabetes, but the causality of the association was not supported by a recent Mendelian study in a global population [1]. Fet-A is a natural inhibitor of insulin receptor tyrosine kinase and contributes to insulin resistance in rodents and humans [2, 3]. In humans, high Fet-A levels are linked to obesity, metabolic syndromes, and diabetes [4]. Recent studies suggested that Fet-A is an adipokine; however, its expression in adipose tissue remains unclear depending on the type of cells and species investigated $[5,6]$. In a recent study, we assessed Fet-A levels in plasma and human subcutaneous adipose tissue (hSAT) of obese adults with and without diabetes [6] and found that Fet-A protein levels in hSAT were significantly increased in obese adults with diabetes. We suggested that Fet-A was present in hSAT and peripheral blood mononuclear cells (PBMCs) as a result of its uptake from circulation rather than its endogenous expression because Fet-A mRNA was detected neither in hSAT nor in PBMCs.

\footnotetext{
* Correspondence: ali.tiss@dasmaninstitute.org

${ }^{2}$ Biochemistry and Molecular Biology department, Research Division, Dasman Diabetes Institute, P.O. Box1180, 15462 Dasman, Kuwait

Full list of author information is available at the end of the article
}

In our proposed model, hSAT would be a reservoir for FetA. However, we do not exclude the possibility that hSAT marginally contributes to Fet-A production and has a potentially limited paracrine and/or autocrine function [6]. Jialal and Pahwa recently commented on our study and expressed concerns regarding the lack of Fet-A expression in hSAT [5].

In an attempt to address these concerns, we analyzed and compared the expression of Fet-A in hSAT, epididymal visceral mouse adipose tissue (eWAT), and inguinal mouse adipose tissue (iWAT) biopsies using RT-PCR. Additionally, we assessed Fet-A expression during the differentiation of human primary preadipocytes from hSAT, human visceral adipose tissue (hVAT), and mice 3 T3-L1 cells. Our results revealed high Fet-A expression in both mice biopsies; however, we did not detect any Fet-A transcripts in hSAT (Fig. 1a), which was consistent with the findings of previous reports, including ours [6-8].

Remarkably, when we differentiated human preadipocytes, we did not detect any Fet-A transcripts in the hSAT preadipocytes, hVAT preadipocytes, or hSAT adipocytes; however, Fet-A transcripts were present in the late stages of differentiation in hVAT adipocytes (Fig. 1b). This observation was further confirmed at Fet-A protein levels (data not shown). 


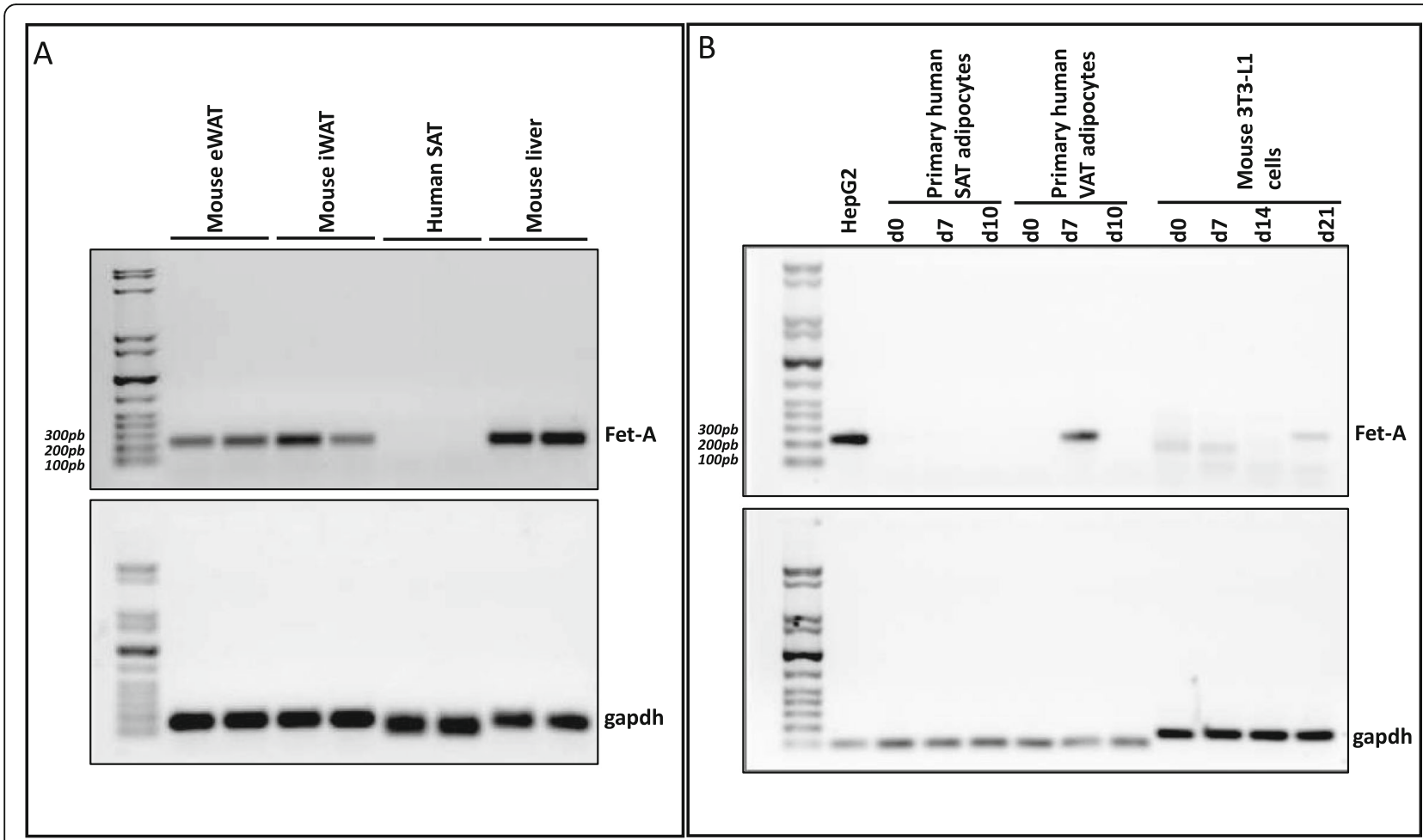

Fig. 1 Fetuin-A expression in human and mouse adipose tissue and adipocytes. a Total RNA was isolated from human and mouse tissue biopsies and subjected to RT-PCR and agarose gel analysis. $\mathbf{b}$ Total RNA was isolated from human primary subcutaneous adipose tissue and visceral adipose tissue adipocytes and mouse 3T3-L1 cells at various stages of differentiation and subjected to RT-PCR and agarose gel analysis. 15 ng of PCR products were loaded on the agarose gel for all samples, excluding mouse liver and HepG2 cell positive controls, for which only 5 ng were loaded. The gels represent three independent experiments

Similarly, Hennig et al. previously reported the absence of FetA mRNA in hSAT preadipocytes [8]. In our previous study, we reported the absence of Fet-A mRNA in 3 T3-L1 preadipocytes and differentiated adipocytes at day 8 [6]. Based on the suggestion by Jialal and Pahwa [5], we differentiated 3 T3L1 preadipocytes for a longer period and detected faint Fet-A transcript at day 21 at the anticipated size. As previously reported, we also detected faint bands at days 0 and 7, although with reduced sizes compared with the positive control (Fig. 1b). Nevertheless, sequencing the PCR products at various differentiation days, including day 21 , did not match with Fet-A sequence (data not shown). It is essential to stress that Fet-A transcripts in hVAT and 3 T3-L1 differentiated adipocytes were only detected at high PCR amplification cycles compared with the positive controls, including HepG2, mouse liver, and GAPDH (32, 35 versus 17, 18 and 16 cycles, respectively). The difference in amplification (15-17 cycles) reflects a difference of several thousand-fold less expression of Fet-A in differentiated hVAT and 3 T3-L1 adipocytes. The low level of expression in tissues is often considered Fet-A negative. For instance, Jahnen-Dechent et al. detected Fet-A mRNA in FetA knockout mice despite the mice having been shown to lack Fet-A AHSG [9]. Furthermore, Song et al. estimated the expression ratio of Fet-A in human and mice liver compared with their respective adipose tissues and reported ratios of 7314-fold and 86-fold, respectively [10], thus highlighting both the lower levels of Fet-A expression in adipose tissue and the much lower expression levels in human adipose tissue compared with that in mouse adipose tissue.

In conclusion, we confirm the high expression of Fet$\mathrm{A}$ in mouse adipose tissue depots and its absence in hSAT and its primary cells. Fet-A was detected in human primary VAT cells at low levels but only after differentiation. Therefore, the marginal expression of Fet-A in hVAT could indicate Fet-A specific local action and requires further investigation.

\section{Material and methods}

hSAT biopsies were collected from consented adults and processed during our previous study [6]. Mouse biopsies were provided by Dr. R. Ahmad (Dasman Diabetes Institute, Kuwait). All primers used, quantitative RT-PCR, and agarose gel analysis were according to our previous study [6]. Primary preadipocyte cells from hSAT and hVAT (\#PT5001 and \#PT5005, Lonza, USA) were processed and differentiated according to the supplier's instructions. 


\section{Abbreviations}

eWAT: epididymal visceral mouse adipose tissue; Fet-A: Fetuin-A; hSAT: human subcutaneous adipose tissue; hVAT: human visceral adipose tissue; iWAT: inguinal mouse adipose tissue; PBMC: Peripheral blood mononuclear cell

\section{Acknowledgements}

We thank the staff at the Tissue Bank at Dasman Diabetes Institute for processing the human biopsies, Dr. R. Ahmad for providing mouse RNA, and Mr. M. Melhem for performing PCR product sequencing. Enago (www.enago. com) is thanked for the English language review.

\section{Authors' contributions}

AK and AT designed the study. SK and DM performed the experiments. AK, SK, DM and AT analyzed the data. AK and AT wrote and revised the manuscript. The authors read and approved the final manuscript.

\section{Funding}

This work was supported by the Kuwait Foundation for the Advancement of Sciences under project (RA-2010-003).

\section{Availability of data and materials}

Not applicable.

\section{Ethics approval and consent to participate}

Written informed consent was obtained from all participants prior to starting this study (RA-2010-003), which was approved by the Review Board of Dasman Diabetes Institute and was conducted in line with the principles of the Declaration of Helsinki, as we previously detailed [6].

\section{Consent for publication}

Not applicable.

\section{Competing interests}

The authors declare that they have no competing interests.

\section{Author details}

${ }^{1}$ Genetics and Bioinformatics department, Research Division, Dasman Diabetes Institute, Kuwait City, Kuwait. ${ }^{2}$ Biochemistry and Molecular Biology department, Research Division, Dasman Diabetes Institute, P.O. Box1180, 15462 Dasman, Kuwait.

Received: 5 May 2019 Accepted: 9 March 2020

Published online: 12 March 2020

\section{References}

1. Kroger J, Meidtner K, Stefan N, Guevara M, Kerrison ND, Ardanaz E, Aune D, Boeing H, Dorronsoro M, Dow C, Fagherazzi G, Franks PW, Freisling H, Gunter MJ, Huerta JM, Kaaks R, Key TJ, Khaw KT, Krogh V, Kuhn T, Mancini FR, Mattiello A, Nilsson PM, Olsen A, Overvad K, Palli D, Quiros JR, Rolandsson O, Sacerdote C, Sala N, Salamanca-Fernandez E, Sluijs I, AMW S, Tjonneland A, Tsilidis KK, Tumino R, van der Schouw YT, Forouhi NG, Sharp SJ, Langenberg C, Riboli E, Schulze MB, Wareham NJ. Circulating Fetuin-A and Risk of Type 2 Diabetes: A Mendelian Randomization Analysis. Diabetes. 2018;67:1200-5.

2. Mathews ST, Rakhade S, Zhou X, Parker GC, Coscina DV, Grunberger G. Fetuin-null mice are protected against obesity and insulin resistance associated with aging. Biochem Biophys Res Commun. 2006:350:437-43.

3. Stefan N, Hennige AM, Staiger H, Machann J, Schick F, Krober SM, Machicao F, Fritsche A, Haring HU. Alpha2-Heremans-Schmid glycoprotein/fetuin-a is associated with insulin resistance and fat accumulation in the liver in humans. Diabetes Care. 2006;29:853-7.

4. Trepanowski JF, Mey J, Varady KA. Fetuin-a: a novel link between obesity and related complications. Int J Obes. 2015;39:734-41.

5. Jialal I, Pahwa R. Fetuin-a is also an adipokine. Lipids Health Dis. 2019;18:73.

6. Khadir A, Kavalakatt S, Madhu D, Hammad M, Devarajan S, Tuomilehto J, Tiss A. Fetuin-a levels are increased in the adipose tissue of diabetic obese humans but not in circulation. Lipids Health Dis. 2018;17:291.

7. Witasp A, Carrero JJ, Hammarqvist F, Qureshi AR, Heimburger O, Schalling $M$, Lindholm B, Nordfors L, Stenvinkel P. Expression of osteoprotegerin in human fat tissue; implications for chronic kidney disease. Eur J Clin Investig. 2011;41:498-506.

8. Hennige AM, Staiger H, Wicke C, Machicao F, Fritsche A, Haring HU, Stefan $N$. Fetuin-a induces cytokine expression and suppresses adiponectin production. PLoS One. 2008;3:e1765.

9. Jahnen-Dechent W, Brylka L, Schinke T, McKee MD. Letter to the editor, concerning: "FGF23-regulated production of fetuin-a (AHSG) in osteocytes". Bone. 2016;93:223-4.

10. Song Y, Ahn J, Suh Y, Davis ME, Lee K. Identification of novel tissue-specific genes by analysis of microarray databases: a human and mouse model. PLoS One. 2013;8:e64483.

\section{Publisher's Note}

Springer Nature remains neutral with regard to jurisdictional claims in published maps and institutional affiliations.

\section{Ready to submit your research? Choose BMC and benefit from:}

- fast, convenient online submission

- thorough peer review by experienced researchers in your field

- rapid publication on acceptance

- support for research data, including large and complex data types

- gold Open Access which fosters wider collaboration and increased citations

- maximum visibility for your research: over $100 \mathrm{M}$ website views per year

At BMC, research is always in progress.

Learn more biomedcentral.com/submissions 